\title{
Representation and agency in diplomacy: How Kosovo came to agree to the Rambouillet accords
}

\author{
By Tobias Wille
}

Cluster of Excellence 'The Formation of Normative Orders', Goethe University Frankfurt, Max-Horkheimer-Straße 2, 60323 Frankfurt (Main), Germany

Email: wille@soz.uni-frankfurt.de

This is a post-peer-review, pre-copyedit version of the following article:

Wille, Tobias. 2019. "Representation and Agency in Diplomacy: How Kosovo Came to Agree to the Rambouillet Accords." Journal of International Relations and Development 22 (4): 808-31. (doi: 10.1057/s41268-017-0120-2)

\begin{abstract}
This article traces how Kosovo came to agree to the Rambouillet accords, with the aim of exploring the nexus between diplomatic representation and international agency. It demonstrates that, in the world of diplomacy, entities like 'Kosovo' can act only when they are carefully staged. Thus far, however, the academic discipline of International Relations (IR) has largely failed to acknowledge the role of diplomacy in the constitution of agency. Therefore, to clarify what is at stake in the theoretical debate, I begin with a systematic discussion of how IR has conceived of diplomatic representation. Taking cue from Bruno Latour's and Lisa Disch's writings on political representation, I then suggest an alternative understanding of diplomacy that takes its performative character seriously. Equipped with this conceptual toolkit, I subsequently turn to the story of Kosovo's representation at the Rambouillet conference held in 1999. Tracing how Kosovo Albanians and their international supporters staged Kosovo's diplomatic performance, and how the Yugoslav/Serbian delegation tried to undermine it, I demonstrate that diplomatic representation can indeed generate agency. I also identify three factors that influence whether or not a diplomatic performance succeeds in making those who are represented act: recognition by other international actors, practical competence, and the alignment of the represented.
\end{abstract}

Keywords: agency; diplomacy; Kosovo; performativity; political representation; practice theory 


\section{Introduction}

It was a peculiar group of people that boarded the two white Falcon executive jets at the little airfield 15 kilometres south of Pristina in the early afternoon of 6 February, 1999. For a decade, Ibrahim Rugova - poet, professor of literature, and president of the internationally not recognised Republic of Kosova - had led the non-violent resistance movement of Kosovo Albanians ${ }^{1}$ against what they regarded as the hostile occupation of their homeland by Serbia. ${ }^{2}$ He was accompanied by three members of his party, the Democratic League of Kosovo (LDK). Among those boarding the planes were also four members of the United Democrat Movement (LBD) which in early 1998 had formed around Rexhep Qosja, another eminent Kosovo writer and long-time political opponent of Rugova. Furthermore, two well-known journalists had been invited to join the group as representatives of Kosovo's civil society. Then, suddenly, one of the orange armoured vehicles used by the Organisation for Security and Co-operation in Europe (OSCE) mission in Kosovo pulled up on the tarmac and delivered three members of the Kosovo Liberation Army (KLA) directly to the airplanes. ${ }^{3}$ Their armed resistance movement had obscure roots in Leninist groups which had mobilised both in Kosovo and among the Albanian diaspora since the late 1970s. ${ }^{4}$ In the fall of 1997, the KLA had stepped up its until then sporadic attacks and began openly confronting the Yugoslav army and Serbian security forces in Kosovo. Since the Serbian government regarded them as terrorists and had initially refused to guarantee them safe conduct, the three KLA members who were to join the group had to be escorted by the OSCE observer mission in Kosovo from the hills of the Drenica region to the airfield.

This diverse group of individuals - some of whom had never met before while others shared a long history of political enmity - was to represent Kosovo in high-stakes negotiations at the Château de Rambouillet near Paris. Disunited and unexperienced in international politics as they were, they nonetheless succeeded in engaging in diplomacy in such a way that Kosovo was ultimately able to agree to the Rambouillet accords. Since Yugoslav president Slobodan Milošević refused to sign the accords, this singular act of diplomacy by Kosovo cleared the way for NATO's military campaign against Yugoslavia,

\footnotetext{
${ }^{1}$ I use the terms 'Kosovo Albanian' and 'Kosovar' interchangeably to denote the ethnic Albanian population of Kosovo.

2 For a general account of Kosovo Albanians' political struggle during the 1990s, see Judah (2002); for a comprehensive discussion of its political and legal aspects, see Bellamy (2002), Weller (2009); on non-violent resistance in Kosovo, see Clark (2000), Kostovicova (2005).

3 'Kosovo Albanians arrive for peace talks', Agence France Presse, 6 February, 1999.

4 On the history of the KLA, see Perritt (2008), Pettifer (2012).
} 
the United Nations' interim administration of the territory, and eventually Kosovo's independence. Reflecting on this astonishing transformation of a handful of political activists and resistance fighters into a diplomatic delegation that could act on behalf of Kosovo, I want to ask the following questions: What does it take for a diplomatic representation to succeed? How does a group of people come to act through the words and deeds of its diplomatic representatives? The present article thus asks how collectives can become actors in international politics through diplomacy. ${ }^{5}$ My main strategy for exploring this question will be to trace in detail what the Kosovars and those international representatives sympathetic to their cause did in order to ensure that Kosovo's diplomatic performance was successful, and what the Yugoslav/Serbian representatives and their allies did to undermine it. 6

Before engaging with the empirical material, some theoretical ground-clearing will be necessary because the academic discipline of International Relations (IR) in large part subscribes, either explicitly or implicitly, to an understanding of diplomatic representation which rests on the assumption of fully constituted actors, and thus cannot make sense of phenomena such as Kosovo's emergent agency at Rambouillet. To clarify the theoretical issues at stake, I will offer a systematic discussion of how IR has conceived of diplomatic representation until now. As I will argue, large parts of the discipline subscribe to a constative view of diplomatic representation according to which those who are represented exist independently from the representation. For the proponents of this view, diplomatic performances merely convey an already constituted will in a more or less truthful way. A more convincing theoretical perspective recognises that diplomatic representation necessarily transforms the will it transmits. Viewed from such a perspective, acts of diplomacy are performative in the sense that they enable collectives to act in particular settings in which they otherwise would not be able to act. Diplomats actively define, rather than merely transmit, the identity and interests of those they represent.

In outlining what a performative account of diplomatic representation might look like, I will introduce a specific understanding of political representation that I find in the

\footnotetext{
${ }^{5}$ Discussions of the problem of agency in the context of diplomacy usually focus on the extent to which individual diplomats can make a difference in face of structural constraint; for an overview, see Adler-Nissen (2016). However, I am not concerned with this question in the present article.

6 With its focus on how actors at the very margins of the international system struggled to come to terms with the world of diplomacy, this article takes its inspiration from recent studies that have engaged with unofficial forms of diplomacy and liminal spaces; specifically Bátora and Hynek (2014), McConnell (2017), McConnell et al. (2012).
} 
writings of Bruno Latour and Lisa Disch. In the detailed discussion of Kosovo's representation at the Rambouillet conference that follows, I will then try to bring Latour's and Disch's ideas into dialogue with empirical material in an attempt to gain a deeper understanding of what is required for a diplomatic representation to succeed. A detailed account of the practical problems faced by the Kosovars and their international supporters will enable me to identify three factors that appear to have an important influence on whether or not a diplomatic performance succeeds in making those who are represented act: recognition by other international actors, practical competence, and the alignment of those who are represented behind the act of representation. I will conclude the article with a discussion of some of the implications of my argument for the academic study of diplomacy.

\section{How to make sense of diplomatic representation?}

The central theoretical claim I want to defend in this article is that diplomatic performances do not merely represent given international actors but, on the contrary, first give rise to the agency of these actors, i.e. their ability to act in international politics. Agency in international politics, as I understand it, is thus not something which is simply given but something which emerges from practice. While traditionally IR has treated the question of who can act as an analytical problem to be resolved before one engages in actual research, this article treats the question of agency as one which can be studied empirically by enquiring into what is required for agency to emerge in particular situations (see also the introduction to this special issue, Braun et al. 2018). Before turning to the story of Kosovo's diplomatic performance at Rambouillet, however, some theoretical work needs to be done. In order to clarify the precise implications of the claim that diplomacy generates agency, I will begin this section with a systematic discussion of the various alternative ways of conceptualising diplomatic representation. Then I will introduce some ideas from the works of Latour and Disch about how to understand political representation, which will provide a conceptual frame for my enquiry into how Kosovo achieved agency in international politics through its diplomatic representation at the Rambouillet conference.

There is almost universal agreement in the academic literature on diplomacy about the importance of the role of representation (e.g. Jönsson and Hall 2005, Ch. 5; Neumann 2011, Ch. 4; Sharp 1999). Nonetheless, it is conceptually far from clear what exactly diplomatic representation is and how it works. In what follows, in order to clarify the theoretical options, I will offer a systematisation of alternative conceptualisations of diplomatic representation. The first theoretical choice is whether one understands 
diplomatic representation as constative or performative. ${ }^{7}$ Constative accounts assume that the represented form a collective with an identity and will that exist independently of the representation. Such a view rests implicitly or explicitly on a particular understanding of political representation that has developed out of contractualist political philosophy (see Pitkin 1967). The essence of this understanding is pointedly summarised by Laclau (2007, p. 97) when he writes:

What is involved in a process of representation? Essentially the fictio iuris that somebody is present in a place from which he or she is materially absent. The representation is the process by which somebody else - the representative 'substitutes for' and at the same time 'embodies' the represented. The conditions for a perfect representation would be met, it seems, when the representation is a direct process of transmission of the will of the represented, when the act of representation is totally transparent in relation to that will.

For diplomacy, such a constative understanding of representation means that diplomatic representatives are assumed to transmit truthfully and transparently the will of those they represent. In contrast, performative accounts of diplomatic representation, which I will discuss in detail below, take diplomatic performances to be involved in the production of what, according to the juridical fiction of representation, they appear merely to transmit.

In its most straightforward form, the constative account of diplomatic representation simply assumes that diplomatic representatives transmit truthfully the identity and interests of those they represent. In IR, this view often remains implicit because authors do not even consider the role of diplomacy on the assumption that it has no causal influence on political outcomes. Certainly, all IR theories that conceive of states or nations as unitary actors fall in the category of constative approaches to diplomatic representation, regardless of whether they think that states maximise utility or follow norms. However, theories that disaggregate the state can also have a constative understanding of diplomatic representation if they assume that diplomats transmit more or less truthfully the will of those they represent. Such more complex constative accounts also assume that the collective which is represented exists independently of its representation, but they question how far the diplomats stick to their instructions. The most popular version of this argument is formulated in the vocabulary of principal-agent theory. If a state or government is a rational actor and if this actor has to rely on the services of another equally rational actor, namely the diplomat, to represent it in certain settings, then the rational interests of the two actors may very well differ. This gives rise to the following questions: What factors determine a diplomat's autonomy from the

\footnotetext{
${ }^{7}$ I take this distinction from speech act theory; see Austin (1962).
} 
principal? How do principal-agent dynamics shape political outcomes? And are the decisions which diplomats make on behalf of their principals legitimate? (Jönsson and Hall 2005, Ch. 5) A more sociological variant of this argument does not conceive of diplomats as utility-maximising individuals, but as an epistemic community that follows its own rationality. This then gives rise to the question of whether diplomats are 'agents of international cooperation or simply transmission belts for states' ${ }^{8}$

In this article, however, I want to use the story of Kosovo's appearance at the Rambouillet conference to sketch out a performative account of diplomatic representation. In contrast to the constative accounts discussed above, such a perspective rests on the idea that what is represented does not exist independently of the representation. It is only through diplomatic performances that collectives gain the capacity to act in international politics. One of the first to spell out this idea in IR was Constantinou (1996, p. 105), who observed that 'in agency [...] one deals with the need of establishing the fiction of working representation, that is, how the sovereign subject voices its words and makes known its will'. Such a performative conception of diplomatic representation clearly echoes what poststructuralists have maintained in regard to states more generally, namely that they are 'subjects in process' and 'the ontological effects of practices which are performatively enacted' (Weber 1998, p. 78; see also Campbell 1992). I would argue that there are two ways of conceptualising diplomatic representation as performative: a radical and a moderate one. In the radical variant, the will and identity of the represented are imagined to emerge from the performance alone. In its purest form, probably no scholar ever has put forth this argument. There is, however, a tendency in poststructuralist texts to reduce diplomacy to the symbolic. In this form, shared structures of meaning enable and constrain diplomatic performances, but other factors such as relations to other actors, materiality, and embodiment remain excluded. ${ }^{9}$

A moderate performative understanding of diplomatic representation, a variant of which I want to explore through my discussion of the Rambouillet conference, assumes not only that there is a shared horizon of meaning against which the performance becomes intelligible, but also that there are real people who are being represented. In contrast to a constative understanding of diplomacy, however, the transmission of the identity and will of the represented is thought of neither as direct nor as transparent. As we shall see when I return to the story of Kosovo's representation at the Rambouillet conference, whether

${ }^{8}$ Cross (2008, p. 2); a similar argument could be made in regard to 'communities of practice', even though I am not aware of any text that does so explicitly; see Adler (2008), Bicchi (2011).

${ }^{9}$ See Wille (2016); for a general critique of poststructuralist IR scholarship along these lines, see Ringmar (2016). 
or not there is an alignment between the represented interests and the representation is, in a certain sense, an empirical question. That they are not identical, however, is a logical necessity. This somewhat philosophical thought is expressed by Laclau (2007, p. 98) when he writes that 'the representative inscribes an interest in a complex reality different from that in which the interest was originally formulated and, in doing so, he or she constructs and transforms that interest. But the representative is thus also transforming the identity of the represented'. Consequently, representation is never direct and transparent, but always impure and opaque. It necessarily transforms what it transmits.

There is a strong current in the academic literature on diplomacy which contends that diplomacy is not just an ephemeral phenomenon (as those who subscribe to a constative understanding of diplomatic representation often believe), but that it is a constitutive element of international politics. Recently, Sending et al. (2015, p. 17), for example, have argued that 'diplomacy is a socially emergent phenomenon and as such it produces effects of its own on world politics' (see also Pouliot and Cornut 2015). Such a position has obvious implications for how diplomatic representation should be conceptualised. If diplomacy somehow contributes to constituting international politics, then it probably also plays a role in constituting its actors. And indeed there is a strong current in this literature which assumes that diplomats contribute to the constitution of the actors they represent, 'that diplomacy is what states do' and 'that states are what diplomacy does' (Neumann 2011, p. 3). What has been missing until now, however, is a clear theoretical account of how diplomacy constitutes international actors.

If diplomatic representation is conceived in performative terms, the crucial question becomes what makes such a representation successful. In other words, what does it take for a diplomatic representation to make those who are represented act? ${ }^{10}$ This was precisely the question which preoccupied the Kosovars and their international supporters at the Rambouillet conference. Explicating and refining some arguments about political representation from Latour's earlier writings (esp. 1999, 2004), Disch (2008, 2010 ) has suggested that there is a symmetry between the political representation of the people and the scientific representation of natural processes. A good scientific experiment carefully stages a situation in which nature can reveal itself. Similarly, a good political representation creates a situation in which the people can reveal themselves:

This would mean that the art of the politician, no less than that of the experimenter, would consist in 'designing devious plots and careful staging that make an actant',

\footnotetext{
10 I understand 'success' with regard to diplomatic representation in a narrow sense to mean that those who are represented indeed act. One could also conceive of 'success' in a broader sense which takes into account whether the act actually brought about the intended consequences.
} 
in this case a citizenry or constituency, 'participate in new and unexpected situations that will actively define it'. (Disch 2010, p. 272; quoting from Latour 1999, p. 123).

In his more recent writings, Latour $(2003,2013$, Ch. 12) has explained how he sees political representation along very similar lines. There he describes political representation as an iterative circular movement that is about 'transforming the many into one' through representation and the subsequent 'retransformation of the one into several' as orders are obeyed by the members of the collective (Latour 2003, p. 149). Thus, artful politics gives rise for a moment to the collective as a single actor; but then agency diffuses once again as individuals carry out what the collective has decided. The question for all political representation is thus 'how to connect beings to others so that the collective holds together' under the strange condition that 'the political has to allow beings to pass through and come back while tracing an envelope that defines, for a time, the "we", the group in the process of self-production' (Latour 2013, p. 338).

Latour and Disch both highlight the situatedness and the processual character of political representation. According to them, representation is a situational achievement; it depends on a carefully staged setting in which the will of the represented can reveal itself. And representation cannot be achieved once and for all; rather, it is an iterative process through which the represented are kept united behind what thus becomes their collective will. I propose that we can conceive of diplomacy in similar terms. Collectives can act internationally only when their representation is carefully staged as a performance in a diplomatic setting; international agency is the precarious effect of such diplomatic performances, rather than something that can be achieved once and for all. However, these rather abstract ideas do not provide a specific answer to the question of when diplomatic performances succeed and when they fail, i.e. when they make the represented act and when they do not. ${ }^{11}$ In the following, therefore, I will present the story of the Rambouillet conference as an empirical illustration of what is required in order to make a group of people act in international politics. I will show that the Kosovo Albanians and their international supporters were particularly concerned that the Kosovar delegation should be recognised by the international community as legitimate spokespersons of Kosovo; moreover, they were also concerned about the practical competence of the delegation members and about the alignment of those in whose name the delegation spoke.

\footnotetext{
${ }^{11}$ In the vocabulary of speech act theory, these could be characterised as the 'felicity conditions' under which a performance can produce a certain effect; see Austin (1962) and Latour (2013, Ch. 2).
} 


\section{Assembling the cast and setting the stage}

In the months leading up to the Rambouillet Conference, the international community had tried to contain the conflict in Kosovo. These efforts had been overseen by the so-called Contact Group of powerful states with an interest in the region, which had been formed in 1994 to address the conflict in Bosnia and comprised France, Germany, Italy, Russia, the United Kingdom, and the United States. ${ }^{12}$ On the ground, the former United States diplomat and architect of the Dayton Agreement, Richard Holbrooke, the US ambassador to Skopje, Christopher Hill, and the Austrian ambassador to Yugoslavia and European Union envoy for Kosovo, Wolfgang Petritsch, had tried to mediate between Belgrade and Pristina. Initially, the international community sought to isolate the Kosovo Liberation Army. In February 1998, the US special envoy to the Balkans, Robert Gelbard, had said in Belgrade that the KLA 'is, without any questions, a terrorist group'. ${ }^{13}$ This statement, which reflected the State Department policy vis-à-vis the underground army at the time (Crawford 2001, p. 506), clearly excluded the possibility of the KLA being part of a diplomatic process. Soon, however, it became evident that without the participation of the KLA no meaningful settlement could be reached. In July 1998, a first official meeting between Christopher Hill and the KLA leadership took place in Likovac (Hill 2014, pp. 137-138). From then on, the mediators not only shuttled between Belgrade and Pristina but also regularly sought out the KLA leadership to discuss their proposals for a settlement. However, this did not mean that the LDK and the KLA would happily join forces. As then US Secretary of State Madeleine Albright (2013, p. 394) writes in her memoirs, the challenge was 'to persuade the Albanians to unify their negotiating team and agree on a set of achievable goals', which was difficult since 'the various Albanian leaders spoke of each other with disdain, sometimes threatened each other with violence, and couldn't agree on a negotiating agenda'.

The official aim of the meeting at Rambouillet was to finalise an agreement on which US envoy Christopher Hill had been working together with his EU counterpart Wolfgang Petritsch since June 1998 (Hill 2014, pp. 129-130). As the British Foreign Minister Robin Cook explained on the first day of the conference, 'three quarters of the solution are already there. [...] In order to complete the work and fill in the remaining 25 [per cent] we

12 On the role of the Contact Group during the Kosovo conflict, see Prantl (2006, Ch. 7). ${ }^{13}$ A month later, after a brutal counter-insurgency campaign by Serbian security forces, which cost the lives of several civilians, Gelbard qualified this statement saying that the KLA 'committed terrorist acts', but has 'not been classified legally by the U.S. Government as a terrorist organization'; 'U.S. says it might consider attacking Serbs', New York Times, 13 March, 1998. 
have to have the parties together, which is the purpose of this meeting'. ${ }^{14}$ What the mediators were offering to the Kosovars was a NATO-enforced interim settlement which would end the violence and postpone a final solution of the Kosovo question for three years. The proposal both accorded extensive autonomy to the Kosovars and reaffirmed the territorial integrity of Serbia, while remaining intentionally ambiguous about whether the latter provision was limited to the three-year interim period or not (Petritsch et al. 1999, pp. 180-183). Since it was more than doubtful whether Milošević would agree to such a deal, the US representatives in particular were also already planning for a failure of the talks. As Hill writes in his memoirs, at the outset of the negotiations, he 'decided that what we really needed was an Albanian approval of a document, and a Serb refusal. If both refused, there could be no further action by NATO or any other organization for that matter' (Hill 2014, p. 149). In his much-read account of the Kosovo conflict, British journalist Tim Judah (2002, pp. 198-199) observes that, considering the setup, 'there was a certain amount of theatre in what then followed'. And, indeed, for Kosovo to be able to agree to the accord, its representation at Rambouillet had to be carefully staged.

When the Kosovar delegation arrived at Rambouillet in the afternoon of 6 February, 1999, the mediators had already taken a big step towards successfully staging a diplomatic representation of Kosovo. Ever since the emergence of the KLA, tensions had been running high between the underground army and the Democratic League. Initially, Rugova had even denied the existence of the KLA, claiming that the sporadic attacks being reported were a fabrication of the Serbian secret police to discredit his non-violent movement (Pettifer 2012, p. 114). Understandably, this did not contribute to Rugova's popularity among the leadership of the KLA. But there were also divisions within the LDK. Rugova and his prime minister in exile, Bujar Bukoshi, who joined the delegation in Rambouillet travelling from Germany, had already fallen out in the mid-1990s over the question of whether the LDK should continue on the path of non-violent resistance or enlist its own army to fight the Serbian forces in Kosovo. The KLA, for its part, was a loose organisation with several power centres. In fact, Hill and Petritsch had spent a large part of the summer of 1998 on attempts to find the right interlocutors with whom they could enter into negotiations (Hill 2014, pp. 134-140). Thus, the group who arrived at Rambouillet was far from being a unified delegation which could speak with one voice. Hill (2014, p. 149) writes of Jacques Huntzinger, the French ambassador to Macedonia, who had driven with the OSCE into Drenica to pick up the KLA representatives and had then flown with the delegation to Paris, that 'given the degree of antipathy that existed

14 Joint press conference by Hubert Védrine and Robin Cook, 6 February, 1999, printed in Krieger (2001, pp. 258-259). 
among the three-headed delegation - Rugova, the KLA, and the "independent intellectuals" from Pristina - I did not envy Jacques's duties that day, herding them onto a plane and enduring the three-hour trip to Paris'.

Despite the deep divisions within the political factions in Kosovo, the Western members of the Contact Group were determined to stage Kosovo's diplomatic presence in a way that Kosovo could ultimately sign the accord to be negotiated. And they were quite blunt about it. On the day the Contact Group decided to call the meeting in Rambouillet, Robin Cook, in an interview with the BBC, expressed his confidence that

there will be people from the Kosovo side [...] who will be willing to take part in talks. Ultimately we can't let these talks be held up by one faction or another within the Kosovo community who doesn't want to see them proceed. Those who want war have got to be marginalised and we have got to focus on those who are willing to look at a political way forward. ${ }^{15}$

Some members of the Contact Group were clearly willing to extend a certain level of recognition to those Kosovar political leaders who seemed to be prepared to reach a compromise. Traditionally, international law and IR have understood recognition in international politics as a binary matter: either an entity has full internal and external sovereignty and thus is a full member of the international society of states, or it lacks sovereignty and then it is not an international actor. ${ }^{16}$ Drawing on the philosophy of recognition, however, some scholars (Lindemann and Ringmar 2012; Daase et al. 2015) have recently painted a more differentiated picture of recognition. In pursuing this approach, Biene and Daase (2015, pp. 224-225) have theorised that states seek to influence the behaviour of armed non-state actors by strategically adjusting their recognition along a scale ranging from recognising them as one party to the conflict to recognising them as the sole representatives of their people. A similar argument can be made in regard to how the Contact Group treated Kosovo's representatives at Rambouillet. They were willing to recognise Kosovo as an entity that can act in international politics, albeit certainly not as a sovereign state, in order to pursue a certain agenda of creating order in the Balkans. Apparently, performances can be recognised as diplomacy to a greater or lesser extent. Just as statehood comes in degrees (Clapham 1998), so too does diplomacy.

15 BBC interview with Robin Cook, 29 January, 1999, printed in Petritsch et al. (1999, pp. 272-273).

16 Even within this narrative there are exceptions, such as international organisations, the Holy See, or the Order of Malta, which can engage in diplomacy even though they are not sovereign states; see Bátora and Hynek (2014). 
Comprising virtually the whole political elite of Kosovo, the delegation that arrived in Rambouillet in the afternoon of 6 February, 1999, appeared at least in its composition to be representative of the Albanians of Kosovo. ${ }^{17}$ The Serbian government did what it could to disrupt the diplomatic performance by this ensemble. As we have already seen above, Serbia had refused to guarantee safe conduct to the KLA members under the pretext that they did not have valid passports, and only after intense pressure from the Contact Group did it agree to tolerate the OSCE stunt of escorting the insurgents directly to the airplane which would take them out of the country. Furthermore, Ratko Marković, Serbian Deputy Prime Minister and head of the Yugoslav/Serbian delegation, had told reporters in Paris just one day before the opening of the conference that 'we consider the so-called Kosovo Liberation Army a terrorist organization, and with killers and kidnappers we have nothing to talk about'. ${ }^{18}$ These were clearly attempts to delegitimise the Kosovar delegation and prevent the members of Contact Group from treating Kosovo as a proper diplomatic actor. But the mediators left the Yugoslav/Serbian delegation no choice; they had to face the KLA in a diplomatic setting.

The composition of the Yugoslav/Serbian delegation also reflected Milošević's stance that what had happened in Kosovo was a domestic problem of Serbia and that - whoever these people gathering at Rambouillet were - they represented at most an ethnic minority in Serbia and certainly not a people with a right to determine its own fate. The Yugoslav President did not attend the conference in person. ${ }^{19}$ Instead the delegation was headed by Serbian Deputy Prime Minister Marković, who was joined by Serbian Prime Minister Milan Milutinović in the second week of negotiations. The composition of the delegation thus signalled that the Kosovo issue was an internal affair of the Republic of Serbia which a decade earlier had unilaterally revoked the autonomy of the province. To bolster this point, the delegation used stationary of the Republic of Serbia (and not that of the Federal Republic) for its communication with the mediators (Weller 1999a, p. 226). Furthermore, the Yugoslav/Serbian delegation included a number of individuals who supposedly represented the different communities living in Kosovo, even though they were repudiated by some of the respective community leaders in Kosovo once their presence

\footnotetext{
${ }_{17}$ Bukoshi, who was living in Bonn, and two KLA representatives who had slipped out of Kosovo earlier joined the delegation at Rambouillet.

18 'Peace talks threatened by Serb brinkmanship', Associated Press International, 5 February, 1999.

19 One can only speculate about the reasons for this. Two frequently formulated suspicions are that Milošević was afraid of being arrested on war crimes charges and that he thought he would be more likely to achieve a favourable outcome of the talks by pulling the strings from a distance; see Bellamy (2002, p. 131).
} 
in Rambouillet became known (Weller 1999a, p. 226). This 'rainbow coalition' (Petritsch et al. 1999, p. 279) was intended to bolster Milošević's well-rehearsed claim that the Albanians were just one ethnic group among many in Kosovo (even though in fact they represented the overwhelming majority of the population) and that the Republic of Serbia was taking the rights of all minorities in the province seriously.

Like Latour's artful experimenter, who sets up a trial in which nature can reveal itself, the French hosts of the conference had carefully set the stage in a way they hoped would allow Kosovo to speak. Their 'political laboratory' was a fourteenth-century château which had been sealed off for the negotiations. The Yugoslav/Serbian delegation and the Kosovar delegations were accommodated on different floors with each being assigned a separate conference room where they could work on the drafts presented to them by the mediators. As several of the participants later complained, the rooms were small, had not been refurbished for decades, and in part lacked en suite facilities. As one participant reportedly noted, it 'was not exactly the Congress of Vienna' (Judah 2002, p. 203; see also Hill 2014, p. 148). At least in the early phase of the negotiations, however, the French hosts regaled their guests with opulent meals. Those meals were taken by the Yugoslav/Serbian and Kosovar delegations in two separate but adjourning dining rooms, with the staff of the Contact Group delegations informally alternating between the rooms (Weller 1999a, p. 227). In an attempt to reproduce the secluded atmosphere that had proven conducive to the negotiations at Dayton, the members of the Serbian and the Kosovar delegations were given badges that, in a reversal of common practice, did not permit them to access to the chateau, but signalled to the security personnel that the bearer was to be prevented from leaving the premises which were surrounded by heavy iron fences (Petritsch et al. 1999, p. 278; Weller 2009, p. 123). However, as the mediators would soon realise, thanks to the arrival of the mobile phone, isolating their political experiment from the outside world had become virtually impossible.

\section{Constituting the delegation}

The conference opened with a ceremony at which French President Jacques Chirac, in addition to the two chairmen, Hubert Védrine and Robin Cook, spoke and which both the Kosovar and the Yugoslav/Serb representatives attended. The Kosovo Albanian delegation held its constitutive meeting the following day. Edita Tahiri, who participated in the conference as a member of the LDK group, recalls: 'Hill and Petritsch and Mayorski, the Russian envoy, brought us the draft accord they wanted us to comment on. And to be able to comment, we needed to be a unified delegation, to build committees to address 
different areas of this accord.' 20 The most controversial question was who would head the delegation. The LDK members felt that 'we would send a very wrong message if we have somebody else head the delegation and not President Rugova. He was the only one elected. He was the only one with the power of the vote'. ${ }^{21}$ They were, however, outnumbered by the KLA and LBD representatives, who insisted that KLA's Hashim Thaçi head the delegation. The Kosovars furthermore decided that Hashim Thaçi, Ibrahim Rugova, and Rexhep Qosja together would form a steering group which was also to include Veton Surroi as spokesperson of the delegation (Kola 2003, p. 351). Moreover, the Kosovars at the meeting created a drafting committee, chaired by Fehmi Agani from the LDK, which would work on the proposals presented by the mediators (Petritsch et al. 1999, p. 280; Weller 2009, p. 127). It was also decided that all decisions of the delegation had to be made unanimously. The conclusions of the first delegation meeting were recorded in a short document which was handed to the international mediators. ${ }^{22}$

At their constitutive meeting, the Kosovar delegation also decided to appoint a group of advisors. Both the LDK and the KLA had brought their own entourage of experts and translators to Rambouillet. The KLA's main political advisor was Shinasi Rama, an Albanian with roots in Kosovo, who was pursuing a $\mathrm{PhD}$ in political science at Columbia University in New York. ${ }^{23}$ In addition to their own experts, the LDK had arranged for a handful of international advisors to support the Kosovar delegation. Bujar Bukoshi had invited Marc Weller, ${ }^{24}$ a German international lawyer teaching at Cambridge University, who had advised the government in exile since the London Conference in 1992.25 Furthermore, Bukoshi had arranged for international lawyer Paul Williams and former US diplomat Marshall Harris to support the Kosovar delegation. ${ }^{26}$ Former US ambassador Morton Abramowitz, president of the International Crisis Group and a close friend of Madeleine Albright, followed an invitation of Veton Surroi to come to Rambouillet. ${ }^{27}$ Initially, the French hosts had not admitted the advisors into the château. On Monday, 8 February, 1999, however, the conference authorities gave in and issued five badges to each delegation, which could be used on a revolving basis to bring advisors onto the premises. While, unsurprisingly, there was some argument about who could bring whom

\footnotetext{
${ }^{20}$ Interview with Edita Tahiri, Pristina, 19 May, 2014.

${ }^{21}$ Interview with Skënder Hyseni, Pristina, 22 May, 2014.

22 Conclusions, printed in Tahiri (2001, p. 489).

23 Interview with Shinasi Rama, New York, 25 February, 2015; see Judah (2002, p. 205).

${ }^{24}$ For Weller's own account of the Kosovo conference, see Weller (1999b, 2009).

25 Interview with Bujar Bukoshi, Pristina, 28 September, 2015; Kola (2003, p. 349).

${ }^{26}$ Interview with Marshall Harris, Washington, 27 February, 2015.

27 Interview with Bujar Bukoshi, Pristina, 28 September, 2015; Albright (2013, p. 402).
} 
in, according to Marc Weller (2009, p. 127) the Kosovar delegation soon realised that it was indispensable to have the two international lawyers present at all times, and so 'they were exempted from the daily struggle for badges'.

According to Marshall Harris, Christopher Hill initially opposed the presence of the international advisors. 'He was very upset that we were there. [...] Obviously what we did in the room he could not control.'28 This scepticism is also echoed in Hill's memoirs (2014, p. 130), where he notes that Abramowitz 'rarely encountered a village in the Balkans he didn't want to see turned into an independent state'. Madeleine Albright (2013, p. 402), however, writes that she was pleased that the Kosovars had sought the help of international experts, which she considered appropriate since none of the Kosovars 'had previously participated in a complex negotiation, certainly not on the world stage, and they still had many disagreements among themselves'. While this is correct as far as it goes, it would be more accurate to say that the Kosovar delegates had varying degrees of experience with diplomacy. The LDK group comprised the very people who had conducted Kosovo's informal diplomacy since the early 1990s. They had discussed various drafts of the proposed settlement with Hill and Petritsch during the last year of shuttle diplomacy and probably had a good idea of what would happen at Rambouillet. Furthermore, the 'independent' delegation member Veton Surroi, son of a Yugoslav diplomat and editor of the daily newspaper koha ditore, with his 'elegance, confidence, and articulate sophistication' (Perritt 2008, p. 154), was seen by many observers as the 'voice of reason' within the Kosovar delegation (Judah 2002, p. 209; see also Bellamy 2002, p. 133; Perritt 2009, p. 59) and played a central role in brokering the final outcome of the conference. Most other members of the delegation, however, had less experience when it came to the practice of international diplomacy. Skënder Hyseni, who participated in the conference as an advisor to Ibrahim Rugova, remembers: 'It was not easy. [...] We had people in the delegation who hardly knew the distinction between an ambassador and a foreign minister. And some of them would address Robin Cook with "Mr Ambassador". You know [...] you get an idea of what problems we were facing'. ${ }^{29}$

It thus appears to have been of paramount importance to the Kosovars to get their diplomacy right. They felt uneasy about what Latour (2013, p. 348) describes as the 'know-how concerning speaking well and speaking badly, acting well and acting badly in the political realm', know-how that is 'dispersed in institutions, buried in practices, captive in our imaginations and in our judgments'. Since the Kosovars had little experience with diplomacy, they decided to enrol the help of experts, of people who knew how to do diplomacy well. Recently, Adler-Nissen and Pouliot (2014) have argued that

28 Interview with Marshall Harris, Washington, 27 February, 2015.

${ }^{29}$ Interview with Skënder Hyseni, Pristina, 22 May, 2014. 
practical competence in diplomatic contexts can serve as an intrinsic power resource. ${ }^{30}$ In international organisations, states with strong and well-resourced foreign policy bureaucracies, such as the United States, the United Kingdom and France, are more likely to realise their interests thanks to their practical competence. 'The size of permanent missions, the availability of in-house legal expertise, the capacity to draft policy documents, and information and communications technologies do play a large role in the practical unfolding of multilateral diplomacy by opening up space for competence claims and the wielding of influence' (Adler-Nissen and Pouliot 2014, p. 894). The anxiety of the Kosovars and the concern about their lack of experience with diplomacy displayed by Albright and others suggest that practical competence might not only allow actors to shape political outcomes, but also that it may be crucial to the emergence of agency itself. Whether a diplomatic performance succeeds or falls flat, whether it makes the collective act or not, thus appears to depend at least in part on whether those who perform it do so in the right way or not.

\section{Negotiating with Kosovo}

Formally, the negotiations were conducted as proximity talks at which the mediators alternately speak to the parties trying to formulate a compromise everyone can agree to in the end. This is how Christopher Hill described the process at a press conference:

What happens is you get comments from one side, you go in another room and you get comments from the other side. You try to incorporate the more sensible of the comments, and then you bring out a new draft and, lo and behold, they look and they say, 'Where did this come from?' Well, it obviously came from the other side and they don't like that. And then they say, 'Well, what happened to our idea?' and you say 'Sorry, the other side couldn't allow that in there and neither could we.'31

In the first week of the conference, however, this is not quite how the negotiations progressed. While the Kosovars with the support of their legal advisors swiftly began preparing written comments on the drafts that were presented to them, the Serbian delegation was stalling. During the day, they were seen lounging in the public areas of the castle, while at night they would get drunk and sing, so that - as Weller (2009, p. 126) ironically notes - at one point 'an informal protest was made against the singing of Serbian

${ }^{30}$ A concern with practical knowledge and competence is a thread that runs through the whole recent debate on international practices; see Adler and Pouliot (2011), Bueger and Gadinger (2015), and Neumann (2002).

${ }^{31}$ Press briefing by the Contact Group negotiators, 18 February, 1999, printed in Weller (1999a, pp. 441-444). 
patriotic songs deep into the night in the Yugoslav/Serbian delegation room'; but to the frustration of the other residents of the château, far from giving in, the Yugoslav/Serbian delegation 'requested and received a piano (this request was heartily supported by the Russian mediator), to help it while away the days and evenings'.

The drafting work within the Kosovo Albanian delegation was itself a delicate negotiating process between the three factions. As LBD member Hydajet Hyseni explains: 'Mr Rugova was willing to accept everything they were proposing, the first version, the KLA was resisting that, and we were in the middle'. ${ }^{32}$ Therefore, the drafting committee chaired by Fehmi Agani, with the assistance of its international advisors, went through the documents in a 'draining process, the difficulty of which' in Marc Weller's assessment 'may not have been fully appreciated by the conference chairs and the negotiators'; these comments were then discussed in the plenary of the delegation (Weller 2009, p. 127). The differences between the factions where also echoed in the attitudes of their respective experts. Shinasi Rama, the principal advisor of the KLA faction recalls:

I assumed that these agreements were more than a formality. Others assumed that these were a mere formality. [... ] Particularly the foreign advisors believed that this 'bunch of peasants' had no choice but to sign. And we basically told them that we were not a bunch of peasants. There was a lot of infighting between the advisors. ${ }^{33}$

Apparently there were huge differences between the assessments of how far Kosovo could and should go in making concessions. Notwithstanding these difficulties, the Kosovar delegation managed swiftly to produce comments on the proposal, which they presented to the mediators.

After eight days without much noticeable activity by the Yugoslav/Serbian delegation, on 14 February, the foreign ministers of the Contact Group met in Rambouillet and decided to extend the talks by one week. On 16 February, Madeleine Albright sent Christopher Hill to Belgrade to speak to Slobodan Milošević and tell him 'that he'd better get serious on the negotiations' (Hill 2014, p. 150). On his trip, Hill was accompanied by a member of the Yugoslav/Serbian delegation, Nikola Šainović. The Kosovars protested against this breach of protocol and later, by way of compensation, received the permission for Hashim Thaçi to leave the château for consultations with the KLA leadership (Weller 1999a, p. 229, n. 28). Hours after Hill's return, the Yugoslav/Serbian delegation submitted comments on the draft agreement to the mediators (Bellamy 2002, p. 137). According to Petritsch, these comments were 'of little help' since they revoked concessions that had already been made

\footnotetext{
${ }^{32}$ Interview with Hydajet Hyseni, Pristina, 20 May, 2014.

${ }^{33}$ Interview with Shinasi Rama, New York, 25 February, 2015.
} 
by the delegation in discussions with the mediators (Petritsch et al. 1999, p. 286, my translation).

In response to the written comments they had received, on 18 February the international mediators presented the parties with a 'final draft' of the agreement. This draft, which appeared to mainly reflect the concerns of the Serbian side, was vehemently rejected by the Kosovar delegation, which issued a strongly worded statement indicating that it considered the submission of a substantially new document two days before the scheduled conclusion of the conference [...] to be a breach of faith, and that it refused even to receive this document' (Weller 2009, p. 129). Weller (1999b, pp. 229-230) speculates that 'Kosovo's reasonable written comments may have deceived the negotiators into thinking that the Kosovo delegation was fully united behind the Rambouillet project and willing to sign up to any political settlement provided it brought NATO enforcement with it'. The mood in the delegation deteriorated further, particularly among the KLA members, when they were handed a copy of the 'non-negotiable' annexes on the civilian and military implementation, according to which KLA would have to be demilitarised, a prospect that left the KLA members and their supporters in the delegation 'in a state of shock' (Weller 2009, p. 130).

Although diplomatic performances are situated, they are not isolated. For a diplomatic performance to be successful, it needs to resonate with what is happening in other places. It can succeed only if the represented do not renounce their representation. In Latour's (2013, p. 341) terms, it is the 'principal infelicity condition of the political to have its course interrupted, the relay broken off'. As Christopher Hill's trip to Belgrade demonstrates, the mediators knew that this held true for the Yugoslav/Serb delegation. The mediators were acutely aware that Milošević was pulling the strings. While he had representatives in Rambouillet, it was also clear that they could not agree to anything without his consent. The mediators were less aware, it seems, of how fragile a representation the Kosovars were performing. While the most prominent members of the LDK, including President Rugova and Prime Minister Bukoshi, were present, it was far from clear who could decide on behalf of the KLA to sign any agreement. The military operations in Kosovo were carried out by powerful regional commanders. These commanders were controlled only formally by the general staff whose political directorate was negotiating at Rambouillet (Perritt 2008, pp. 81-85). Furthermore, there was an opaque network of members and supporters in the Albanian diaspora, some of whom had been involved in preparations for an armed struggle since the late 1970s while others had shifted their sympathies only recently from Rugova's LDK to the underground army (see Hockenos 2003).

In August 1998, the general staff of the KLA had appointed Adem Demaçi, an eminent dissident and public intellectual who had spent 28 years in Yugoslav prisons, as its 
political representative. Demaçi had opposed vocally Kosovo's participation in the Rambouillet conference because in his opinion it did not offer a path to independence (Bellamy 2002, p. 128). When the general staff decided that the KLA would nevertheless attend, he opted to stay in Kosovo. A reliable historical account of the dynamics within the KLA leadership during the Rambouillet negotiations is still lacking. It is certain, however, that the general staff and the zone commanders took a keen interest in the negotiations. According to Ramush Haradinaj, the commander of the Dukagjini region, they were not able to get hold of the documents that were negotiated at Rambouillet by fax or other means (Hamzaj 2000, p. 149). Consequently, they had to rely for information on what those in the château reported via telephone. ${ }^{34}$ On 18 February, Hashim Thaçi, as recompense for the trip taken by Šainović with Hill to Belgrade, was allowed to leave the château and travelled to Ljubljana, where he consulted with Adem Demaçi. Details of the conversation are not known but, after his return, Thaçi reportedly took an even harder stance (Hill 2014, p. 153; Kola 2003, p. 353). As the negotiations were drawing to a close, the KLA commanders appointed Sylejman Selimi as chief of staff. With quite a few of the KLA's key leaders tied up in delicate negotiations, this must have appeared to many observers at the time as a coup, or at least as 'considerable and somewhat confusing changes' (Weller 1999b, p. 233) within the KLA leadership. ${ }^{35}$ Selimi swiftly inserted himself into the negotiations by instructing Thaçi via phone on pain of death not to accept any agreement unless it guaranteed a NATO intervention and independence (Bellamy 2002, p. 140). Given this background, it seems somewhat unfair when certain commentators condemn Thaçi on the grounds that 'much of his time was spent wandering about the château talking on his mobile phone to people outside while failing to give leadership inside' (Judah 2002, p. 208). For Kosovo's representation at Rambouillet not to fail it was crucial to unite the commanders in Kosovo behind whatever decision was to be taken. Otherwise, they would renounce the agreement and the Kosovars would literally be reduced from being a fragile international actor to being a hopelessly divided secessionist movement.

\section{Pushing the Kosovo Albanians across the finish line}

When the foreign ministers of the Contact Group confronted the Kosovar delegation on Saturday, 20 February, which was supposed to be the last day of the conference, in a session which, according to Albright, had from the start an 'inquisitional feeling', Thaçi

\footnotetext{
34 Interview with Ramush Haradinaj, Pristina, 11 June, 2015.

35 Haradinaj later claimed that Demaçi's influence over the zone commanders was not decisive and that in appointing Selimi they acted as 'as soldiers' and 'as fighters', and thus presumably not as politicians; Hamzaj (2000, p. 147).
} 
gave evasive answers to the question of whether the Kosovars accepted the framework or not, while Rugova, Qosja, and Surroi remained silent (Albright 2013, p. 404; see also Fischer 2007, p. 142). In order to ensure that the conference did not end in complete failure, the foreign ministers of the Contact Group then decided to extend the talks for another three days. Now, all of the attention was focused on the Kosovars. The rationale behind the concerted diplomatic effort was elaborated in surprisingly blunt terms by State Department spokesperson James Rubin at a press briefing:

We cannot put the full amount of pressure [on the Serbs] if we don't get an agreement from the Kosovar Albanians. [...] It has never been the view of NATO or the United States that a Serb refusal along with a Kosovar Albanian refusal would necessarily lead to NATO military action. [...] In order to move towards military action, it has to be clear that the Serbs were responsible. ${ }^{36}$

For NATO to be able to intervene, the Kosovo Albanians needed to sign the accords. This was made clear to the Kosovars by the US delegation in no uncertain terms. The message was: 'If you accept [the proposal], you will move toward a future of prosperity, democracy, and integration with Europe. Reject it, and the outcome will be a war you will lose, along with international support.' (Albright 2013, p. 402; see also Tahiri 2001, p. 333)

During the final three days of the negotiations, Madeleine Albright spent a significant amount of time in the château trying-as her spokesperson Rubin phrased it at the same press briefing-to 'help push the Kosovar Albanians across the finish line'. ${ }^{37}$ The US mediators and their Contact Group counterparts now pulled out all the stops to get the Kosovo Albanians to accept the deal. On 22 February, the famous Albanian writer Ismail Kadare sent an emotional letter to the delegation in which he urged them to sign the agreement. The letter convinced Rexhep Qosja, who held Kadare in high regard, to change his position, which left Hashim Thaçi isolated in his resistance to the agreement (Petritsch et al. 1999, pp. 302-305). The mediators also reached out to the Albanian government. Prime Minister Pandeli Majko made a public statement urging the KLA to sign and sent his Foreign Minister Pascal Milo to France to talk to the delegation. ${ }^{38}$ To disperse the misgivings of the KLA faction about whether or not NATO would really deploy troops to Kosovo, a meeting with NATO's Supreme Commander in Europe, General Wesley Clark, was arranged. Since the French hosts of the conference did not want to allow him to enter the château, he flew from Mons in Belgium to a military airfield near Rambouillet where he met the five KLA representatives and explained to them how the alliance intended to

\footnotetext{
36 Press briefing by James Rubin, 21 February, 1999, printed in Weller (1999a: 451). 37 Ibid.

38 'Talks on Kosovo near breakdown', New York Times, 23 February, 1999.
} 
implement the agreement. ${ }^{39}$ But all to no avail. In the end, Thaçi, now isolated within the delegation, still refused to sign. Since the delegation had agreed to make all decisions unanimously, this meant that Kosovo would not agree to the accord.

As the delegation member who was the most persistent in his refusal to sign the accord, Hashim Thaçi 'lived through several long hours of being worked over by Albright' (Weller 2009, p. 131). She writes in her memoirs:

I tried a variety of tactics. First I told Thaçi what a great potential leader he was. When that didn't work, I said we were disappointed in him, that if he thought we would bomb the Serbs even if the Albanians rejected the agreement, he was wrong. We could never get NATO support for that. 'On the other hand', I said, 'if you say yes and the Serbs say no, NATO will strike and go on striking until the Serb forces are out and NATO can go in. You will have security. And you will be able to govern yourselves.' (Albright 2013, p. 406)

But all efforts proved to be in vain. Judging from what many of those present at the events have written, it is clear that the politically unexperienced Thaçi could barely endure the pressure. He seemed nervous and unresponsive (Petritsch et al. 1999, p. 301), increasingly lost countenance (Fischer 2007, p. 142), and appeared 'clearly abashed and almost tearful' (Albright 2013, p. 406). On the one hand, everybody was warning him of the catastrophic consequences it would have if the Kosovars let the negotiations fail, but on the other hand he did not have a mandate to agree to the terms that were offered. Asked by Hill why he could not sign, Thaçi reportedly answered: 'If I agree to this, I will go home and they will kill me.'40

For days, the mediators had entertained the possibility that the Kosovo delegation could consent to the agreement in principle and then receive some time to consult with its various constituencies (Albright 2013, p. 407). According to Petritsch, Thaçi had agreed to such a solution in principle during the night from 22 to 23 February (Petritsch et al. 1999, p. 308). As the definitive deadline set by the Contact Group of 3:00 pm on 23 February, 1999, approached, the delegation's spokesperson Veton Surroi took the initiative of proposing a formal statement according to which 'the Delegation of Kosova with consensus understands that it can sign the agreement in two weeks after consultation with the people of Kosova, political and military institutions'. ${ }^{41}$ The

39 Ibid.; see also Albright (2013, p. 405) and Hill (2014, pp. 152-153).

40 Hill (2014, p. 153); according to Madeleine Albright (2013, p. 406), Thaçi had made a similar remark to James Rubin.

41 Statement by the delegation of Kosovo, 23 February, 1999, printed in Weller (1999a, p. 471); see Albright (2013, p. 407), Hill (2014, pp. 154-155) and Weller (2009, p. 134). 
declaration was then, with the consent of the delegation, signed by Surroi in his capacity as spokesperson, thus relieving Thaçi of the burden of having to decide either to commit fully to the accords or to let the negotiations fail with all of the consequences. The outcome of the conference was thus 'somewhat confusing', but it allowed 'Kosovo' to argue that its delegation 'had in fact accepted the text as the definite outcome of the negotiations and that it would probably sign, subject to consultation at home' (Weller 2009, p. 135). Pressed by a journalist to explain what exactly the Kosovars had committed to, Secretary Albright explained at the following press conference:

I guess in diplomatic parlance, what they've done is agree to this in principle. [...] You know, for the Serbs to agree, all they have to do is make one phone call. For the Kosovars, it means, really as they are learning about democracy and engaging with other people, it means consulting with [their people back in Kosovo]. ${ }^{42}$

In other words: since the Kosovars did not have the political institutions in place to commit their polity to the agreement based on the act of a single person, the US government was willing to freeze the negotiations so that the Kosovo leaders could return to their various constituencies and unite them behind the decision to sign through a local and decentralised mode of consensus building.

After the Rambouillet conference, the members of the Kosovar delegation returned to Kosovo to convince their respective constituencies of the merits of the agreement reached. During this period, negotiators Hill and Petritsch remained in contact with the various factions through meetings and telephone calls (Petritsch et al. 1999, p. 321). To aid the process, former US Senator Bob Dole, who enjoyed a reputation as a long-standing supporter of the Kosovo Albanians, was sent to the region to convince the KLA to sign (since the Yugoslav authorities denied him a visa the meetings had to take place in Skopje) (Weller 2009, p. 150). German foreign minister Joschka Fischer, whose government at the time held the EU presidency, also travelled to Pristina (Fischer 2007, p. 147). After two weeks, on 15 March, 1999, the Kosovar and Yugoslav/Serbian delegations reconvened as requested by the Contact Group, this time at the Paris International Conference Center on Avenue Kléber. The Kosovars officially informed the international mediators that they were willing to sign the agreement on the first day of the meeting. By that time, Slobodan Milošević must have decided to provoke a NATO intervention. ${ }^{43}$ At

\footnotetext{
42 Press conference by Madeleine Albright, 23 February, 1999, printed in Weller (1999a, pp. 472-474).

43 One can only speculate about Milošević's reasoning. A plausible explanation is that he expected only a short bombing campaign after which NATO would offer him a better deal. Sell (2002, p. 301) argues in his biography of the Serb leader that 'Milošević thought that he could outlast NATO in a duel of wills'.
} 
least, his negotiators had drafted a new proposal which excluded everything that had been agreed upon at Rambouillet and, tellingly, as the first proposed change had erased the word 'peace' from the title of the document (Weller 1999b, p. 234). On 18 March, Ibrahim Rugova, Hashim Thaçi, Rexhep Qosja and Veton Surroi signed the accords in the presence of the three international negotiators. However, only Christopher Hill and Wolfgang Petritsch witnessed the act with their own signatures, while Boris Mayorski did not. Russia was already distancing itself from the outcome of the conference. Six days later, on 24 March, NATO commenced its bombing campaign against Yugoslavia.

\section{Conclusion}

The Kosovars had to wait a further nine years until the conditions were finally favourable for a declaration of independence to be recognised by a considerable number of states. On 17 February, 2008, after a further lengthy process of internationally mediated negotiations, the members of the Kosovo Assembly solemnly declared Kosovo to be an independent state. ${ }^{44}$ But even today, only 112 out of 193 UN members recognise Kosovo and, in particular, Serbia and Russia still fiercely oppose its independence. Thus one certainly cannot say that the Kosovar delegation in 1999 at the Rambouillet conference managed to establish Kosovo's international agency once and for all. Quite the contrary, whether or not Kosovo is an international actor, and if yes what kind of actor, has remained fiercely contested. Nevertheless, the momentary achievement of diplomatic representation that allowed Kosovo to act internationally in 1999 had momentous consequences. Only because Kosovo was able to negotiate and ultimately accept the Rambouillet accords were other actors willing to intervene militarily in what would otherwise have been an internal affair of Yugoslavia and Serbia. Kosovo's representation at Rambouillet was a diplomatic performance that clearly made a difference. In conclusion, I will discuss some of the implications the moderate performative understanding of diplomatic representation I have sketched out in this article has for IR.

The story of Kosovo's representation at Rambouillet is a particularly clear case of a diplomatic performance creating international agency. The detailed analysis of this specific case has shown how diplomacy can create agency. Before the conference began, no fully constituted international subject named 'Kosovo' even existed. And since there was no constituted subject with a clearly discernible will to be represented, its appearance at Rambouillet could only have been an effect of the diplomatic performance itself. This is not to claim that engaging in the ritual of representation was all that

\footnotetext{
${ }^{44}$ On the process that led to Kosovo's declaration of independence, see Perritt (2009) and Weller (2009).
} 
mattered. Exploring the practical problems faced by the Kosovars and their international supporters, I have argued that recognition by other international actors, practical competence, and the alignment of the various groups represented behind the act of representation are important factors that determine whether a representation actually brings about international agency or whether it falls flat. It was clear to the members of the Contact Group that Kosovo could act at the conference only if they recognised what the members of the Kosovar delegation were doing as diplomacy. Furthermore, the unease the Kosovars felt having stumbled onto the international stage indicates that practical competence plays an important role. To compensate for their lack of experience, former Western diplomats, international lawyers, and other experts had to be enrolled as advisors. Finally, I have demonstrated that Kosovo's diplomatic performance almost failed because those in whose name the delegation spoke threatened to disavow the representation. The performative account of diplomatic representation I have given in this article is thus moderate in the sense that it understands the diplomatic performance as embedded in various practices which place constraints on who can make whom act in international politics. The three factors I have identified-recognition, competence, and alignment-certainly do not amount to a full-blown moderate performative theory of diplomacy. However, my hope is that they can at least serve as a starting point for building such a theory.

My argument that diplomatic performances give rise to agency is intended as part of the larger agenda of convincing the community of IR scholars that diplomacy matters (Constantinou 1994; Der Derian 1987; Sharp 1999). If states and other international actors cannot simply act, but can act only by carefully staging their representation, diplomacy will not only have a significant impact on political outcomes but, at a deeper level, it will also affect who can act and who will be acted upon. As I have argued above, however, most of the central debates in IR remain ignorant of the importance of diplomacy, whether as a result of IR's 'structural bias' (Rathbun 2014, p. 1) or of its adherence to a 'substantialist ontology' (Adler-Nissen 2015) which mistakes social processes for stable entities. What IR needs is thus a conceptual toolkit to make sense of the processes through which international politics in general, and its actors in particular, are constituted through acts of diplomacy. Taking stock of the debate between rationalist and constructivist approaches in IR - which many still regard as the 'great debate' of our time - Fearon and Wendt (2002, p. 52), two important representatives of rationalism and constructivism, respectively, have stressed that the role of "performativity" in the constitution of actors' is an important yet thus far underexplored theme. A theory of diplomacy that appreciates the performative element of diplomatic representation has the potential to shed light on this very question. At the same time, we need to be careful not to overstretch the argument by claiming that diplomacy is the only source of 
international agency. As the contributions to this special issue (Abrahamsson and Dányi 2018; Bueger 2018; Noyes 2018; see also Schindler 2014) demonstrate forcefully, agency in international politics is complicated and it can emerge from many practices. The challenge for a performative account of diplomacy is ultimately to grasp how diplomacy overlaps and interacts with these practices as it gives shape to international politics and its actors.

\section{Acknowledgements}

I would like to thank the interviewees on whose accounts this article builds for their time and their willingness to share their recollections of the events at Rambouillet with me. Sedat Burrniku, Arban Mehmeti, Ariana Musliu Shoshi, and Meriton Shoshi helped me to make sense of Kosovo politics and to arrange interviews. I am grateful to Benjamin Braun, Christopher Daase, Kristina Lepold, Christian Reus-Smit, Erik Ringmar, Berthold Rittberger, and Sebastian Schindler, as well as to the anonymous reviewers and the editors of $J I R D$, for their helpful comments on various drafts of this article.

\section{References}

Abrahamsson, Sebastian, and Endre Dányi. 2018. Becoming Stronger by Becoming Weaker: The Hunger Strike as a Mode of Doing Politics. Journal of International Relations and Development (forthcoming).

Adler, Emanuel. 2008. The Spread of Security Communities: Communities of Practice, Selfrestraint, and NATO's Post-Cold War Transformation. European Journal of International Relations 14 (2): 195-230.

Adler, Emanuel, and Vincent Pouliot. 2011. International Practices. International Theory 3 (1): 1-36.

Adler-Nissen, Rebecca. 2016. Diplomatic Agency. In The SAGE Handbook of Diplomacy, ed. Costas M. Constantinou, Pauline Kerr, and Paul Sharp, 92-103. London: Sage.

Adler-Nissen, Rebecca. 2015. Conclusion: Relationalism or Why Diplomats Find International Relations Theory Strange. In Diplomacy and the Making of World Politics, eds. Ole Jacob Sending, Vincent Pouliot and Iver B. Neumann, 284-308. Cambridge: Cambridge University Press.

Adler-Nissen, Rebecca, and Vincent Pouliot. 2014. Power in Practice: Negotiating the International Intervention in Libya. European Journal of International Relations 20 (4): 889-911. 
Albright, Madeleine. 2013. Madam Secretary. New York: Harper Collins.

Austin, John L. 1962. How to Do Things with Words. Oxford: Clarendon Press.

Bátora, Jozef, and Nik Hynek. 2014. Fringe Players and the Diplomatic Order: The New Heteronomy?. Hondmills: Palgrave Macmillan.

Bellamy, Alex J. 2002. Kosovo and International Society. Houndmills: Palgrave.

Bicchi, Federica. 2011. The EU as a Community of Practice: Foreign Policy Communications in the COREU Network. Journal of European Public Policy 18 (8): 11151132.

Biene, Janusz, and Christopher Daase. 2015. Gradual Recognition: Curbing Non-state Violence in Asymmetric Conflict. In Recognition in International Relations: Rethinking a Political Concept in a Global Context, ed. Christopher Daase, Caroline Fehl, Anna Geis, and Georgios Kolliarakis, 220-236. Houndmills: Palgrave Macmillan.

Braun, Benjamin, Sebastian Schindler, and Tobias Wille. 2018. Rethinking Agency in International Relations: Performativity, Performances, and Actor-Networks. Journal of International Relations and Development (forthcoming).

Bueger, Christian. 2018. Performing Piracy: A Note on the Multiplicity of Agency. Journal of International Relations and Development (forthcoming).

Bueger, Christian, and Frank Gadinger. 2015. The Play of International Practice. International Studies Quarterly 59 (3): 449-460.

Campbell, David. 1992. Writing Security: United States Foreign Policy and the Politics of Identity. Minneapolis: University of Minnesota Press.

Clapham, Christopher. 1998. Degrees of Statehood. Review of International Studies 24 (2): 143-157.

Clark, Howard. 2000. Civil Resistance in Kosovo. London: Pluto Press.

Constantinou, Costas M. 1996. On the Way to Diplomacy. Minneapolis: University of Minnesota Press.

Constantinou, Costas M. 1994. Diplomatic Representations ... Or Who Framed the Ambassadors? Millennium: Journal of International Studies 23 (1): 1-23.

Crawford, Timothy W. 2001. Pivotal Deterrence and the Kosovo War: Why the Holbrooke Agreement Failed. Political Science Quarterly 116 (4): 499-523.

Cross, Mai'a K. Davis. 2008. The European Diplomatic Corps: Diplomats and International Cooperation from Westphalia to Maastricht. Houndmills: Palgrave Macmillan. 
Daase, Christopher, Caroline Fehl, Anna Geis, and Georgios Kolliarakis (eds.). 2015. Recognition in International Relations: Rethinking a Political Concept in a Global Context. Houndmills: Palgrave Macmillan.

Der Derian, James. 1987. Mediating Estrangement: A Theory for Diplomacy. Review of International Studies 13 (2): 91-110.

Disch, Lisa. 2010. "Faitiche"-izing the People: What Representative Democracy Might Learn from Science Studies. In Political Matter: Technoscience, Democracy, and Public Life, ed. Bruce Braun, and Sarah Whatmore, 267-296. Minneapolis: University of Minnesota Press.

Disch, Lisa. 2008. Representation as "Spokespersonship": Bruno Latour's Political Theory. Parallax 14 (3): 88-100.

Fearon, James, and Alexander Wendt. 2002. Rationalism v. Constructivism: A Sceptical View. In Handbook of International Relations, eds. Walter Carlsnaes, Thomas RisseKappen and Beth A. Simmons, 52-72. London: Sage.

Fischer, Joschka. 2007. Die Rot-Grünen Jahre: Deutsche Außenpolitik: Vom Kosovo bis zum 11. September [The Red-Green Years: German Foreign Policy: From Kosovo to 9/11], Köln: Kiepenheuer \& Witsch.

Hamzaj, Bardh. 2000. A Narrative About War and Freedom. Pristina: Zëri.

Hill, Christopher R. 2014. Outpost: Life on the Frontlines of American Diplomacy, A Memoir. New York: Simon \& Schuster.

Hockenos, Paul. 2003. Homeland Calling: Exile Patriotism and the Balkan Wars. Ithaca: Cornell University Press.

Jönsson, Christer, and Martin Hall. 2005. Essence of Diplomacy. Houndmills: Palgrave Macmillan.

Judah, Tim. 2002. Kosovo: War and Revenge, 2nd ed. New Haven: Yale University Press.

Kola, Paulin. 2003. The Search for Greater Albania. London: Hurst \& Co.

Kostovicova, Denisa. 2005. Kosovo: The Politics of Identity and Space. London: Routledge.

Krieger, Heike (ed.). 2001. The Kosovo Conflict and International Law: An Analytical Documentation, 1974-1999. Cambridge: Cambridge University Press.

Laclau, Ernesto. 2007. Emancipation(s). London: Verso.

Latour, Bruno. 2013. An Inquiry into Modes of Existence: An Anthropology of the Moderns. Cambridge, MA: Harvard University Press.

Latour, Bruno. 2004. Politics of Nature: How to Bring the Sciences into Democracy. Cambridge, MA: Harvard University Press. 
Latour, Bruno. 2003. What if We Talked Politics a Little? Contemporary Political Theory 2 (2): 143-164.

Latour, Bruno. 1999. Pandora's Hope: Essays on the Reality of Science Studies. Cambridge, MA: Harvard University Press.

Lindemann, Thomas, and Erik Ringmar (eds.). 2012. The International Politics of Recognition. Boulder: Paradigm Publishers.

McConnell, Fiona. 2017. Liminal Geopolitics: The Subjectivity and Spatiality of Diplomacy at the Margins. Transactions of the Institute of British Geographers 42 (1): 139-152.

McConnell, Fiona, Terri Moreau, and Jason Dittmer. 2012. Mimicking State Diplomacy: The Legitimizing Strategies of Unofficial Diplomacies. Geoforum 43 (4): 804-814.

Neumann, Iver B. 2011. At Home with the Diplomats: Inside a European Foreign Ministry. Ithaca: Cornell University Press.

Neumann, Iver B. 2002. Returning Practice to the Linguistic Turn: The Case of Diplomacy. Millennium: Journal of International Studies 31 (3): 627-651.

Noyes, Dorothy. 2018. Blaming the Polish Plumber: Phantom Agents, Invisible Workers, and the Liberal Arena. Journal of International Relations and Development (forthcoming). Perritt, Henry H. 2009. The Road to Independence for Kosovo: A Chronicle of the Ahtisaari Plan. New York: Cambridge University Press.

Perritt, Henry H. 2008. Kosovo Liberation Army: The Inside Story of an Insurgency. Urbana: University of Illinois Press.

Petritsch, Wolfgang, Karl Kaser, and Robert Pichler. 1999. Kosovo, Kosova: Mythen, Daten, Fakten [Kosovo, Kosova: Myths, Dates, Facts]. Klagenfurt: Wieser.

Pettifer, James. 2012. The Kosova Liberation Army: Underground War to Balkan Insurgency, 1948-2001. London: Hurst \& Company.

Pitkin, Hanna Fenichel. 1967. The Concept of Representation. Berkeley: University of California Press.

Pouliot, Vincent, and Jérémie Cornut. 2015. Practice Theory and the Study of Diplomacy: A Research Agenda. Cooperation and Conflict 50 (3): 297-315.

Prantl, Jochen. 2006. The UN Security Council and Informal Groups of States: Complementing or Competing for Governance?. Oxford: Oxford University Press.

Rathbun, Brian C. 2014. Diplomacy's Value: Creating Security in 1920s Europe and the Contemporary Middle East. Ithaca: Cornell University Press. 
Ringmar, Erik. 2016. How the World Stage Makes its Subjects: An Embodied Critique of Constructivist IR Theory. Journal of International Relations and Development 19 (1): 101125.

Schindler, Sebastian. 2014. Man versus State: Contested Agency in the United Nations. Millennium: Journal of International Studies 43 (1): 3-23.

Sell, Louis. 2002. Slobodan Milošević and the Destruction of Yugoslavia. Durham: Duke University Press.

Sending, Ole Jacob, Vincent Pouliot, and Iver B. Neumann. 2015. Introduction. In Diplomacy and the Making of World Politics, eds. Ole Jacob Sending, Vincent Pouliot and Iver B. Neumann, 1-28. Cambridge: Cambridge University Press.

Sharp, Paul. 1999. For Diplomacy: Representation and the Study of International Relations. International Studies Review 1 (1): 33-57.

Tahiri, Edita. 2001. The Rambouillet Conference: Negotiating Process \& Documents. Peja: Dukagjini.

Weber, Cynthia. 1998. Performative States. Millennium: Journal of International Studies 27 (1): 77-95.

Weller, Marc. 2009. Contested Statehood: Kosovo's Struggle for Independence. Oxford: Oxford University Press.

Weller, Marc. 1999a. The Crisis in Kosovo 1989-1999. Cambridge: Documents \& Analysis Publishing.

Weller, Marc. 1999b. The Rambouillet Conference on Kosovo. International Affairs 75 (2): 211-251.

Wille, Tobias. 2016. Diplomatic Cable. In Making Things International 2: Catalysts and Reactions, ed. Mark B. Salter, 166-178. Minneapolis: University of Minnesota Press. 